\title{
Severe amoebic colitis in an HIV-infected male patient
}

\author{
Ezekiel Wong Toh Yoon, ${ }^{1}$ Masaharu Sumii ${ }^{2}$
}

'Hiroshima Kyoritsu Hospital, Hiroshima, Japan

${ }^{2}$ Hiroshima Kinen Hospital, Hiroshima, Japan

\section{Correspondence to}

Dr Ezekiel Wong Toh Yoon, easybs@hotmail.com

Accepted 10 December 2016

\section{DESCRIPTION}

A previously healthy Japanese man aged 67 years was admitted into our hospital after presenting with fever, abdominal pain and watery diarrhoea (occasionally bloody) for 2 weeks. At presentation, he had a fever of $38.9^{\circ} \mathrm{C}$ and diffuse abdominal tenderness. His white cell count was $7440 / \mu \mathrm{L}, \mathrm{C}$ reactive protein $22.18 \mathrm{mg} / \mathrm{dL}$, serum albumin $1.8 \mathrm{~g} / \mathrm{dL}$, potassium $2.9 \mathrm{mmol} / \mathrm{L}$ and blood urea nitrogen was $26.5 \mathrm{mg} / \mathrm{dL}$. Abdominal CT revealed pancolitis with mild splenomegaly but no hepatic lesions. Stool analysis and culture was negative for pathogenic bacteria, Clostridium difficile and tuberculosis.

After conservative treatment with intravenous drip for 2 days, a sigmoidoscopy was performed. Multiple surface to deep ulcerations with yellowish exudate was observed in the rectosigmoid region (figure 1A). Mucosal biopsy revealed acute colitis with the presence of haemophagocytic amoebic

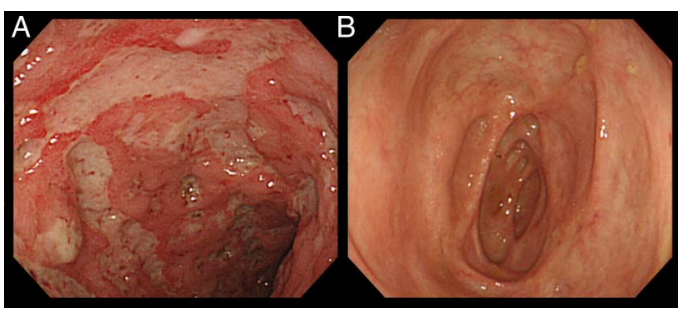

Figure 1 (A) Endoscopic image of the rectosigmoid region revealing multiple surfaces to deep ulcerations with some yellowish exudate. (B) Endoscopic image of the cecum and ascending colon 6 months after discharge revealed multiple ulcer scaring.

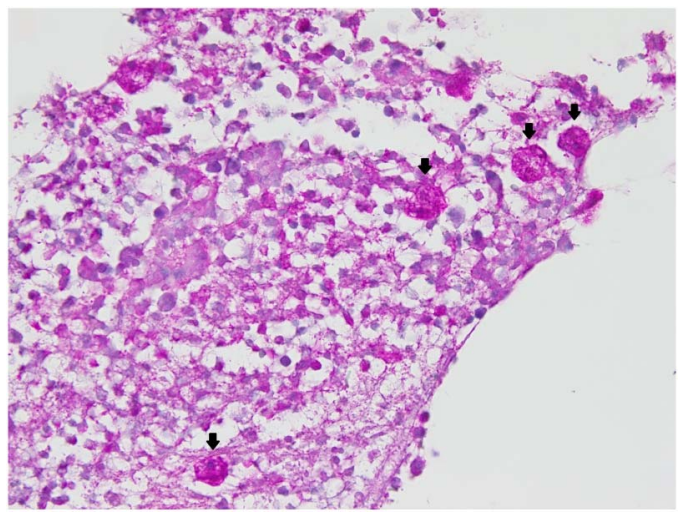

Figure 2 Histological examination with periodic acidSchiff (PAS) staining confirmed the presence of haemophagocytic amoebic trophozoites (arrows) along with chronic inflammatory changes. trophozoites (figure 2, arrows). Microscopic examination of the patient's stool also confirmed the presence of Entamoeba histolytica trophozoites and amoebic serology was positive, confirming the diagnosis of severe amoebic colitis. Clinical symptoms improved remarkably after a 2-week course of metronidazole and he was discharged 3 weeks after admission. Follow-up colonoscopy after 6 months revealed multiple ulcer scars throughout the entire colon (figure 1B). The patient was also screened and tested positive for HIV infection, after which he was referred to a tertiary care hospital for treatment.

Clinical symptoms as well as endoscopic findings of amoebic colitis may closely resemble those of inflammatory bowel diseases and treatment with corticosteroids may cause a mild form to progress to fulminant colitis. ${ }^{12}$ Although HIV-infected patients may have a higher prevalence of $E$. histolytica infestation, they are not necessarily at increased risk for developing invasive disease. ${ }^{3}$ Nevertheless, progress to fulminant colitis in HIV patients have been reported, even though the exact mechanism is unclear.

\section{Learning points}

- Clinical symptoms as well as endoscopic findings of amoebic colitis may closely resemble those of inflammatory bowel diseases.

- HIV-infected patients may have a higher prevalence (not invasive disease) of Entamoeba histolytica infestation.

- Early diagnosis and treatment is important to avoid progress to fulminant colitis.

Contributors EWTY prepared the manuscript. MS provided important instructions.

Competing interests None declared.

Patient consent Obtained.

Provenance and peer review Not commissioned; externally peer reviewed.

\section{REFERENCES}

1 Patel AS, DeRidder PH. Amebic colitis masquerading as acute inflammatory bowel disease: the role of serology in its diagnosis. J Clin Gastroenterol 1989;11:407-10.

2 Shirley DA, Moonah S. Fulminant amebic colitis after corticosteroid therapy: a systematic review. PLoS Neg/ Trop Dis 2016;10: e0004879.

3 Morán $\mathrm{P}$, Ramos F, Ramiro $\mathrm{M}$, et al. Infection by human immunodeficiency virus-1 is not a risk factor for amebiasis. Am J Trop Med Hyg 2005;73:296-300. 
Copyright 2016 BMJ Publishing Group. All rights reserved. For permission to reuse any of this content visit http://group.bmj.com/group/rights-licensing/permissions.

BMJ Case Report Fellows may re-use this article for personal use and teaching without any further permission.

Become a Fellow of BMJ Case Reports today and you can:

- Submit as many cases as you like

- Enjoy fast sympathetic peer review and rapid publication of accepted articles

- Access all the published articles

- Re-use any of the published material for personal use and teaching without further permission

For information on Institutional Fellowships contact consortiasales@bmjgroup.com

Visit casereports.bmj.com for more articles like this and to become a Fellow 